\title{
A Pathologist's perspective of penile carcinoma - an institutional study at Indian Red Cross Hospital, Nellore
}

\author{
Latha PS ${ }^{1}$, Chaitanya $\mathrm{B}^{2}$, Rajasekhar $\mathrm{SR}^{3}$ \\ ${ }^{1}$ Dr P Swarna Latha, MD, Nizam's Institute of Medical Sciences, Hyderabad, Andhra Pradesh. ${ }^{2}$ Dr Balekuduru Chaitanya, \\ MD, Dr NTR University of Health Sciences Vijayawada Andhra Pradesh. ${ }^{3}$ Dr S. Rajasekhar Reddy, M.D, Nizam's Institute \\ of Medical Sciences, Hyderabad Andhra Pradesh, India
}

Address for correspondence: Dr Balekuduru Chaitanya, Email: bharadwaj.chaitanya@yahoo.com

\begin{abstract}
Background: Penile cancer is an unusual malignancy with higher incidence rates in developing countries like India when compared to the Western world. Incidence varies from 0.7-2.3 cases per 100,000 men in urban India and 3 cases per 100,000 men in rural India. In spite of its rarity, it forms a suitable medical model for theranostics. Given this relevance we put forward our departmental experience in a rural Indian setup. Materials and Methods: This is a retrospective three year study of penile SCC patients managed in Indian Red Cross Cancer Hospital, India. Data was compared with similar studies across the world. Results: 23 patients were diagnosed with squamous cell carcinoma of penis during the period of study. We witnessed in this study that a relatively younger age of presentation and early stages prevailing. Higher percentage of involvement of prepuce and body was also noted. Conclusion: Consideration of prognostic histopathological factors may help to tailor appropriate management in this infrequent malignancy.
\end{abstract}

Keywords: Penile Carcinoma, Histopathology, Prognosis

\section{Introduction}

Penile carcinoma is a rare malignancy with incidence peak in the sixth and seventh decades of $\operatorname{life}^{1} .95 \%$ of the cases histologically correspond to squamous cell carcinoma (SCC). ${ }^{2,3}$ There appears to be an ethnic variation in the incidence rates internationally and data from nonwhite patients is limited. ${ }^{4}$ The etiology of penile cancer remains unclear. Strongly associated risk factors include Human Papilloma Virus type 16 (HPV 16) infection, phimosis, lack of circumcision and cigarette smoking. ${ }^{5,6}$ Penile cancer is commonly seen in men of low socio economic status, with poor hygiene contributing significantly.

Due to its superficial location, penile cancer lends itself to early detection and management. However, many patients present for treatment at an advanced stage due to psychological inhibitions. The treatment includes surgery with adjuvant chemoradiotherapy. The surgical procedure may include circumcision, local excision, partial penectomy or even complete penectomy. A 'wait and

Manuscript received: $14^{\text {th }}$ Dec 2013

Reviewed: $26^{\text {th }}$ Dec 2013

Author Corrected; $19^{\text {th }}$ Jan 2014

Accepted for Publication: $30^{\text {th }}$ Jan 2014 watch' policy is often preferred over prophylactic lymphadenectomy. ${ }^{7,8}$

Inguinal lymph node metastases (LNM) are an important prognostic factor in survival for carcinoma of penis. Results from the studies of Pandey et al and Graafland et al showed that extranodal extension, bilateral inguinal metastasis and pelvic node metastasis were prognostic factors in node positive patients., ${ }^{9,10}$ Overall 5-year survival ranges from $27 \%$ in patients with clinically positive nodes to $66 \%$ in patients with clinically negative nodes. ${ }^{11}$

To put forward the data on the biology of this cancer we undertook a review of all cases of penile cancer diagnosed and treated at the Indian Red Cross Society Hospital, Nellore, India from 2010 - 2012.

The aim was to determine the prevalence and clinicopathological correlates of penile cancer in a sample of Indian population and compare the data with other international studies. 


\section{Materials and Methods}

We retrospectively reviewed the medical records of 30 patients with penile lesions from January 2010 to December 2012.

7 patients were found to have only moderate dysplasia on two consecutive histopathological examinations and were excluded.

The remaining 23 patients were diagnosed with penile carcinoma and got themselves treated at the place of study i.e Indian Red Cross Hospital, Nellore, India. To note is the tertiary care nature of this hospital which offers free of cost treatment to the economically backward rural Indian population.

Data included patient age, circumcision status and history of sexually transmitted infections. Penile lesion size, location, presence of palpable inguinal nodes and nature of treatment were noted.

Information was obtained from the Pathology department regarding the histological subtype, degree of differentiation and Pathological stage.

Patients were followed up at 3 month intervals for a period of 1 year uniformly. Follow up included both physical and ultrasound examinations.

Tumour stage was classified according to the 2009 UICC International Union against Cancer Tumour Node Metastasis stage classification system. ${ }^{12}$ Histological grade was assigned according to the modified three tier Broders grading system. ${ }^{13}$ The node status was evaluated by the occurrence of LNM on biopsy during follow up or by the results of lymphadenectomy.

Data was categorized and prognostic factor comparison was performed with the studies of Morrison et al (West Indies, 2009), Kusmawan et al (Indonesia, 2012), Franca Wanick et al ( Brazil, 2011) and Chen et al (China, 2012). ${ }^{14-17}$

\section{Results}

There were 23 penile cancer cases during the study with a mean age of 50.3 years.

The youngest patient was 26 years old and the oldest 90 years.

Most of them had little educational background and were reluctant to reveal data about extramarital sexual contact.
None of them had any associated urinary tract or sexually transmitted infection.

Histologically all 23 patients had SCC of which 1 patient had verrucous variant and 1 had microinvasive variant. Preoperative biopsy and surgical specimens were reviewed and correlated.

Using the modified three level Broder's classification grading was assigned. Grade I (well differentiated tumor) was found in 12 cases $(52.17 \%$ ) and Grade II ( moderate differentiated tumor) was found in 11 cases $(47.83 \%)$. No grade III lesions were diagnosed.

8 cases $(34.78 \%)$ had ulcerative lesions and 7 cases $(30.44 \%)$ had vegetative warty pattern of growth. 8 cases $(34.78 \%)$ had a combined physical morphology i.e. both ulceration and vegetation.

9 cases (39.13\%) with lesion size less than $2 \mathrm{cms}, 9$ cases (39.13\%) with lesion size between 2-5 cms and 5 cases $(21.74 \%)$ with size greater than $5 \mathrm{cms}$ were noted.

Among these, two lesions with size ranging between 2-5 $\mathrm{cms}$ and one lesion greater than $5 \mathrm{cms}$ showed lymph node metastases (LNM).

19 cases $(82.61 \%)$ had proximal penile involvement i.e. glans and prepuce while 4 cases $(17.39 \%)$ had distal i.e. shaft involvement. 11 lesions $(47.83 \%)$ affected glans only, $6(26.09 \%)$ prepuce and $3(13.04 \%)$ involved only body or shaft. 2 cases $(8.69 \%)$ had involvement of both glans and prepuce while one case (4.35\%) showed involvement of both glans and body.

All patients were treated surgically with Partial penectomy - 12 (52.17\%), Total penectomy - $3(13.05 \%)$, excision with biopsy $-8(34.78 \%)$.

3 patients (13.05\%) had inguinal lymphadenectomy on account of metastases. One patient had recurrence following radiotherapy.

13 patients $(56.52 \%)$ had T1 stage, 9 patients $(39.13 \%)$ had T2 and 1 patient $(4.35 \%)$ had T3 stage. No nodal metastases were found in 20 patients $(86.95 \%)$.

2 patients had single inguinal node involvement (N1 $8.70 \%$ ). One patient had three nodes positive for metastasis among 30 excised nodes (N2 - 4.35\%). Findings consistent with HPV infection was found in one patient on $H \& E$ examination. 
Data comparison is summarized in the below table.

Table 1: Patient demographics and potential prognostic factor comparison of our current study with studies worldwide

\begin{tabular}{|c|c|c|c|c|c|c|}
\hline Parameter & $\begin{array}{l}\text { Characteristics of } \\
\text { lesions }\end{array}$ & $\begin{array}{l}\text { Current } \\
\text { study }\end{array}$ & $\begin{array}{l}\text { Morrison } \\
\text { et } \text { al }^{14}\end{array}$ & $\begin{array}{l}\text { Kusmawan } \\
\text { et al }{ }^{15}\end{array}$ & $\begin{array}{l}\text { Wanick et } \\
\text { al }^{16}\end{array}$ & Chen et al $^{17}$ \\
\hline Number & Cases taken & 23 & 22 & 46 & 34 & 55 \\
\hline \multirow[t]{3}{*}{ Age } & $<49$ yrs & 9 & 3 & - & - & 23 \\
\hline & $\geq 49 \mathrm{yrs}$ & 14 & 19 & - & - & 32 \\
\hline & Mean in years & 50.3 & 68 & 58.4 & 64.7 & 53.3 \\
\hline Variant & SCC \& variants & 23 & 21 & 46 & $\begin{array}{l}34 \\
(8-\text { In situ })\end{array}$ & 55 \\
\hline \multirow[t]{2}{*}{ Grade } & I & 12 & 15 & - & 21 & 32 \\
\hline & II + III & $11+0$ & $5+1$ & - & $5+0$ & 23 \\
\hline \multirow[t]{2}{*}{ Location } & $\begin{array}{l}\text { Proximal (Glans/ } \\
\text { Prepuce } \\
\text { Alone or in } \\
\text { combination) }\end{array}$ & 19 & 11 & - & 24 & - \\
\hline & $\begin{array}{l}\text { Distal (Body Alone } \\
\text { or in combination) }\end{array}$ & 4 & 11 & - & 2 & - \\
\hline \multirow[t]{4}{*}{ Size } & $<2 \mathrm{cms}$ & 9 & - & - & 5 & - \\
\hline & $2-5 \mathrm{cms}$ & 9 & - & - & 14 & - \\
\hline & $>5 \mathrm{cms}$ & 5 & - & - & 3 & - \\
\hline & Uninformed & 0 & - & - & 4 & - \\
\hline \multirow[t]{4}{*}{ Morphology } & Ulceration & 8 & - & - & 1 & - \\
\hline & Vegetation & 7 & - & - & 5 & - \\
\hline & Ulcerovegetative & 8 & - & - & 18 & - \\
\hline & Others & 0 & - & - & 2 & - \\
\hline \multirow[t]{5}{*}{ Tumour stage } & $\mathrm{Tx}$ & 0 & 5 & - & 0 & 0 \\
\hline & $\mathrm{T}$ in situ & 0 & 1 & - & 8 & 0 \\
\hline & $\mathrm{T} 1$ & 13 & 4 & - & - & 23 \\
\hline & $\mathrm{T} 2+\mathrm{T} 3$ & $9+1$ & $10+1$ & - & - & 32 \\
\hline & $\mathrm{T} 4$ & 0 & 0 & - & 0 & 0 \\
\hline \multirow[t]{2}{*}{ Node status } & No nodes & 20 & - & 33 & 23 & 42 \\
\hline & LNM & 3 & - & 13 & 3 & 13 \\
\hline \multirow[t]{4}{*}{ Treatment } & Surgical & 23 & 22 & 46 & 16 & 55 \\
\hline & $\begin{array}{l}\text { Biopsy + Partial } \\
\text { penectomy }\end{array}$ & $8+12$ & $8+11$ & 21 & - & 49 \\
\hline & $\begin{array}{l}\text { Total / Complete } \\
\text { penectomy }\end{array}$ & 3 & 3 & 25 & - & 6 \\
\hline & $\begin{array}{l}\text { Lymphadenectomy }+ \\
\text { Biopsy }\end{array}$ & 3 & 6 & $8+5$ & 7 & - \\
\hline
\end{tabular}

\section{Discussion}

The present study demonstrates that penile cancer is uncommon in Indian men. Because of its rarity effectiveness of HPV screening methods is yet to be known and hence they have not been recommended. And because of its low incidence and low rate of follow up, determination of prognostic factors for cancer specific survival has been challenging. Mean age was found to be 50.3 years. This was comparatively lower to the mean age 
from other studies around the world. The prognostic role of age is controversial. The specific reason behind advanced age being a poor prognostic factor is still unknown. ${ }^{18,19}$

Histologically all our cases were SCC which coincides $100 \%$ with the study from Indonesia. This goes well with the existing literature showing SCC as the most frequent histopathological variant accounting for more than $85 \% .^{20,21}$

Histological grade carries an established prognostic significance in malignant lesions. Higher the histological grade, the higher the chances of metastases and poorer the prognosis.

In this regard our study shows an incidence of well moderate differentiated lesions only, with three of the moderately differentiated Grade II lesions showing LNM.

This supports the opinion of Chen et al \& Hegarty et al who concluded that " histological grade and not tumour stage is an important prognostic predictive factor for regional LNM". ${ }^{22}$

Regarding clinical morphology, ulceration in most cases indicates tumour invasion.

In our study ulcerative lesions alone or in combination with vegetative pattern were predominantly noted.

As regards the size of the lesions greater the size, greater the chances of LNM and greater the role of adjuvant therapy. This is well established by our study which clearly shows LNM to be present in lesions greater than 2 cms.

In this study, the predominant location was the glans, alone $(47.83 \%)$ or associated with other regions of the penis $(13.04 \%)$. It was followed by the prepuce, which was affected alone in $26.09 \%$ of cases and body being involved in $13.04 \%$ of cases.

This goes well with the investigated data established showing involvement of glans in $48 \%$ of cases. ${ }^{23,24}$ However our study shows a higher percentage of involvement of prepuce and body when compared to existing data.

The incidence of early stages of the tumour and absence of LNM indicated the need for partial penectomy as can be observed in our study. Histopathologically on $\mathrm{H}$ \& $\mathrm{E}$ stained slides, findings consistent with HPV infection could be found out in one case only. Also, only one case with LNM showed recurrence following radiotherapy.
The work we present has relative limitations: for example, the retrospective 3-year nature of our study design, the relatively small sample size, limitation of high non compliance rate of patients to follow up and the lack as well as the expensive nature of disease related molecular markers.

\section{Conclusion}

Our study puts forward histopathological findings in penile cancer and correlates prognostic factors with other international studies. This helps to understand better the biological behaviour of penile cancer across the world and thereby helps to systematize the manner of treatment.

In addition we highlight the growing need for patient education and protocols for multiprofessional and interdisciplinary approach to this rarer form of malignancy.

\section{Funding: Nil}

\section{Conflict of interest: Nil}

Permission from IRB: Yes

\section{References}

1. Salvioni R, Necchi A, Piva L, Colecchia M, Nicolai N. Penile cancer. Urol Oncol.2009;27(6):677-85.

2. Lynch DFJ, Pettaway CA. Tumors of the penis. In: Walsh PC (eds.)Campbell's Urology. 8th ed. Philadelphia: Elsevier Company; 2002. p2945-81.

3. Micali G, Innocenzi D, Nasca MR, Musumeci ML, Ferrau F, Greco M. Squamous cell carcinoma of the penis. $J$ Am Acad Dermatol.1996;35(3):432-51.

4. Barnholtz-Sloan JS, Maldonado JL, Pow-sang J, Giuliano AR. Incidence trends in primary malignant penile cancer. Urol Oncol.2007;25(5):361-367.

5. Maden C, Sherman KJ, Beckmann AM, Hislop TG, Teh CZ, Ashley RL, Daling JR.. History of circumcision, medical conditions, and sexual activity and risk of penile cancer.J Natl Cancer Inst .1993;85(1):19-24

6. Dillner J, von Krogh G, Horenblas S, Meijer CJ. Etiology of squamous cell carcinoma of the penis. Scandinavian Journal of Urology and Nephrology .2000;205:189-93.

7. Demcow T. The treatment of penile carcinoma: experience in 64 cases. International Urology and Nephrology .1999;31(4):525-31. 
8. Doehn C, Baumgartel M, Jocham D. Surgical therapy of penis carcinoma. Urologe Ausgabe A .2001;40(4): 303-7.

9. Pandey D, Mahajan V, Kannan RR. Prognostic factors in node positive carcinoma of the penis. $J$ Surg Oncol.2006;93(2):133-138.

10. Graafland NM, Moonen LM, van Boven HH, van Werkhoven E, Kerst JM, Horenblas S. Inguinal recurrence following therapeutic lymphadenectomy for node positive penile carcinoma: outcome and implications for management. J Urol.2011;185(3):888-893.

11. Solsona E, Algaba F, Horenblas S, Pizzocaro G, Windahl T. EAU. Guidelines on Penile Cancer. Eur Urol . 2004;46(1):1-8.

12. Sobin LH, Gospodarowicz MK, Wittekind CH. International Union Against Cancer (UICC) TNM Classification of Malignant Tumors. 7th ed. Oxford, U.K. Wiley-Blackwell;

2009

13. Broders AC. Squamous-cell epithelioma of the skin: a study of 256 cases. Ann Surg.1921;73(2):141-160.

14. BF Morrison, B Hanchard, RP Graham, ME Reid. Penile Cancer in Jamaicans Managed at the University Hospital of the West Indies. West Indian Med J .2011; 60(5):525.

15. Kusmawan, E., Bowolaksono, and Widiana, R. The Clinical Features of Penile Cancer Patients at Sanglah General Hospital Bali-Indonesia. Bali Medical Journal (BMJ) .2012;1(1):1-5

16. Fabiana Braga França Wanick, Tullia Cuzzi Teichner, Rosane Silva,, Mônica Maria Ferreira Magnanini, Lucia Maria Soares de Azevedo. Squamous cell carcinoma of the penis: clinicopathologic study of 34 cases. An Bras Dermatol.2011;86(6):1082-91.
17. Xiaopeng Chen, Xuesong Li, Maurice M. Garcia, Kan Gong, Yi Song, Zhisong He, and Liqun Zhou. . Prognostic Factors in Chinese Patients With Penile Invasive Squamous Cell Carcinoma. Journal of Andrology. 2012;33(6):1276-1281.

18. Lopes A, Hidalgo GS, Kowalski LP, Torloni H, Rossi BM, Fonseca FP. Prognostic factors in carcinoma of the penis: multivariate analysis of 145 patients treated with amputation and lymphadenectomy. J Urol.1996;156(5): 1637-1642.

19. Shariat SF, Godoy G, Lotan Y, Droller M, Karakiewicz PI, Raman JD, Isbarn H, Weizer A, Remzi M, Roscigno M, Kikuchi E, Bolenz C, Bensalah K, Koppie TM, Kassouf W, Wheat JC, Zigeuner R, Langner C, Wood CG, Margulis V. Advanced patient age is associated with inferior cancer-specific survival after radical nephroureterectomy. BJU Int.2010;105(12):16721677.

20. Micali G, Innozenci D, Nasca MR. Squamous cell carcinoma of the penis. Journal of American Academy of Dermatology .1996;35(3):432-51.

21. Griffiths TR, Mellon JK. Human papillomavirus and urological tumors: Basic science and role in penile cancer. British Journal Urology.1999;84(5):579-86.

22. Hegarty PK, Kayes O, Freeman A, Christopher N, Ralph DJ, Minhas S. A prospective study of 100 cases of penile cancer managed according to European Association of Urology guidelines. BJU Int.2006;98(3):526-531.

23. Di Capua Sacoto C, Lujan Marco S, Morales Solchaga G, Budia Alba A, Pontones Moreno JL, Jimenez Cruz JF. Cancer of the penis. Our experience in 15 years. Actas Urol Esp.2009;33(2):143-8.

24. Pow-Sang MR, Benavente V, Pow-Sang JE, Morante C, Meza L, Baker M, et al. Cancer of the penis. Cancer Control.2002;9(4):305-314.

\section{How to cite this article?}

Latha PS, Chaitanya B, Rajasekhar SR. A Pathologist's perspective of penile carcinoma - an Institutional study at Indian Red Cross Hospital, Nellore. Int J Med Res Rev 2014;2(1):21-25, 10.17511/ijmrr.2014.i01.05 